PRACE NAUKOWE UNIWERSYTETU EKONOMICZNEGO WE WROCLAWIU

\title{
Bogna Janik
}

Wyższa Szkoła Bankowa w Poznaniu

e-mail: bogna.janik@wsb.poznan.pl

\section{DOPASOWANIE BANKÓW \\ Z EUROPY ŚRODKOWO-WSCHODNIEJ DO MODELU M. JEUCKENA}

\section{ADJUSTMENT OF BANKS FROM CENTRAL AND EASTERN EUROPE TO JEUCKEN'S MODEL}

DOI: $10.15611 /$ pn.2017.478.20

JEL Classification: G21, Q01

Streszczenie: Celem badania jest ustalenie szacunkowego stopnia spełnienia kryteriów Modelu M. Jeuckena przez banki społecznie odpowiedzialne z krajów Europy Środkowo-Wschodniej. Model M. Jeuckena służy do oceny realizacji idei społecznej odpowiedzialności przez banki. Badanie podjęto wiedząc, że model jest przystosowany do oceny banków działających w rozwiniętych, wybranych krajach z wyłączeniem Czech, Polski i Węgier. Oznacza to, że może on niecałkowicie odpowiadać warunkom ekonomicznym, historycznym i zwyczajowym, które panują w tych krajach. Do badania w krajach Europy Środkowo-Wschodniej wytypowano banki spełniające najwyższe standardy społecznej odpowiedzialności, notowane w ramach indeksów: RESPECT, VONIX i CEERIUS. Wyniki badań posłużą do przygotowania modelu, który mógłby spełnić swoją funkcję na rynkach krajów Europy Środkowo-Wschodniej.

Slowa kluczowe: etyczne banki, społeczne banki, banki z indeksów RESPECT, VONIX, CEERIUS, społeczna odpowiedzialność.

Summary: The purpose of the study is to determine the estimated level of fulfillment of the Jeucken's Model criteria by socially responsible banks in Central and Eastern Europe. The object of the research included banks operating in the countries of Central and Eastern Europe and listed in such socially responsible indices as RESPECT, VONIX and CEERIUS. These are the banks which follow high standards of social responsibility, hence they constitute the group representing the highest level of ethics in Central and Eastern European countries. The research was undertaken based on the knowledge that Jeucken's Model was adjusted to the assessment of the banks operating in developed countries, in selected countries excluding Czech, Poland and Hungary. It means that it may be unsuitable to the economic, historical and customary conditions prevailing in these countries. The research results will be later used to prepare a model which would play its role in the markets of Central and Eastern Europe.

Keywords: ethical banks, social banks, banks from RESPECT, VONIX, CEERIUS indices, social responsibility. 


\section{Wstęp}

Etyczna ekonomia czy etyczne finanse stały się bardzo popularne po ostatnim kryzysie finansowym (2007/2008). Wzrost zainteresowania etyczną ekonomią i etycznym finansowaniem był nie tylko widoczny w publikacjach, ale także w praktyce gospodarczej, co potwierdza wzrost wielkości aktywów instytucji pośrednictwa finansowego prowadzących etyczne finanse po kryzysie finansowym 2007/2008 [Remer 2011]. W powszechnej opinii za przyczyny kryzysu obwinia się słabość instytucji finansowych na świecie i w Europie oraz niską efektywność przepływu informacji [Moshirian 2011]. Instytucje finansowe ulegały pokusie nadużycia (moral hazard) poprzez: sprzedawanie produktów finansowych, którymi klient często nie był zainteresowany, i pobieranie ponadprzeciętnych prowizji czy podejmowanie nadmiernego ryzyka z pełnymi konsekwencjami dla klienta [Dowd 2009]. Do wystąpienia ostatniego kryzysu finansowego takie działania nie były piętnowane, a dopiero ich konsekwencje i rozmiar kryzysu przyniosły refleksje. Refleksje w postaci poszukiwania pośrednika „godnego zaufania” nie w kontekście zaufania rozumianego jako utrzymania stabilności finansowej dla całego systemu finansowego, a w szczególności dla systemu bankowego, lecz zaufania rozumianego jako relacji pomiędzy instytucją finansową a jej interesariuszami zarówno wewnętrznymi, jak i zewnętrznymi.

Odchodząc od podejścia instytucjonalnego, ważne jest, aby zastanowić się, jak ważna jest ekonomia etyczna dla społeczeństwa i jaki jest jej możliwy wpływ na funkcjonowanie społeczeństwa. A. Arvidsson i N. Peitersen [2013] opisali kilka możliwych zmian. Po pierwsze, praktyczne wprowadzanie zasad ekonomii etycznej może prawdopodobnie redefiniować pojęcie wzrostu ekonomicznego (poprzez zmianę wartości). Efektem może być otwarcie się na nowe rynki, np. rynki energii ekologicznej. Po drugie, może także wprowadzić pojęcie nowej ekonomicznej racjonalności poprzez występowanie etycznego kapitału. Po trzecie, etyczna ekonomia może wprowadzić nowy rodzaj stabilności, w której krótkoterminowe inwestycje (spekulacje) będą redukowane na rzecz inwestycji długoterminowych. Po czwarte, etyczna ekonomia może redefiniować demokrację. A w końcu może kreować nowy rodzaj racjonalności społecznej zwanej przez iron cage Maxa Webera.

Działalność finansowa związana jest $\mathrm{z}$ wymianą różnych aktywów kapitałowych między osobami prywatnymi, podmiotami gospodarczymi i państwem. W swojej podstawowej formie nie można powiedzieć, czy jest dobra, czy zła, ale jest elementem życia społecznego i służy do osiągania założonych celów. Cele te jednak mogą naruszać sfery społeczne i demokratyczne. Na tym tle restrukturyzacja systemu finansowego, a w szczególności bankowego w kierunku etycznym/społecznym nie powinna podlegać krytyce. Tak jak wcześniej zauważono, etyczne instytucje finanse nie są jednorodne, a ich misje są uwarunkowane czynnikami kulturowymi. Takie różnice zauważa się pomiędzy etycznymi instytucjami finansowym z krajów Europy Środkowo-Wschodniej i z krajów z Europy Zachodniej, Ameryki Północnej, Australii i Oceanii. Na bazie tych refleksji sformułowano cel badania, którym jest pokaza- 
nie różnic pomiędzy poziomem działalności etycznych instytucji finansowych w krajach Europy Środkowo-Wschodniej a krajami Europy Zachodniej, Ameryki Północnej, Australii i Oceanii. Te ostatnie zostały już przebadane pod kątem prowadzenia działalności społecznie odpowiedzialnej przez M. Jeuckena, który skonstruował model oceny banków.

\section{Etyczna bankowość}

W dzisiejszych czasach sformułowanie „etyczna bankowość” czy „bankowość motywowana wartościami” brzmi jak oksymoron, kombinacja słów, które nie mają prawa z sobą współistnieć. Wynika to z postrzegania banków jako ogniw rynkowego systemu finansowego i nadawania im w większości czysto rynkowych konotacji. Jednakże czy osadzenie podmiotów bankowych w bankowym systemie i ograniczanie ich działania poprzez stosowanie norm ostrożnościowych czy rekomendacji sprawia, że banki są zobowiązane do realizacji celów społecznych? Jako pierwsze nasuwa się pytanie, co rozumiemy pod pojęciem bankowości społecznej czy etycznej.

Frans de Clerck [2009] ocenia, że precyzyjna i ujednolicona definicja etycznej bankowości jest trudna do przedstawienia, a wynikać to może $\mathrm{z}$ różnych tradycji, z których pojawiły się etyczne podmioty finansowe. Właściwa interpretacja tego pojęcia będzie zapewne przedmiotem poszukiwań i należy domniemać, że będzie ewoluować. Jednakże na potrzeby niniejszego badania można posłużyć się definicją sformułowaną przez Jamesa Nivena $z$ the Global Alliance from Banking on Values (GABV). Odnosi się on do celów etycznych banków i definiuje je w następujący sposób: banki etyczne to takie, które wpływają pozytywnie bezpośrednio i pośrednio na ludzi, środowisko i kulturę. Ma to wyraz w zwiększeniu akcji kredytowych i inwestycji dla osób i organizacji, które wspierają ludzi, środowisko i kulturę, oraz wykazywaniu, że inne podejście do bankowości jest możliwe i konieczne, oraz że podmioty bankowe aktywnie angażują się w szersze dyskusje na temat przyszłości branży finansowej (wywiad bezpośredni Nivena zob. [Weber, Remer 2011]).

W opracowaniu przygotowanym przez Fondzione Culturale Responsabilita Eti$c a$ w ramach projektu PRICE we współpracy z Polskim Stowarzyszeniem Sprawiedliwego Handlu zaprezentowano różnice pomiędzy bankami etycznymi a konwencjonalnymi bankami komercyjnymi (tab. 1).

R. Milano [2011] przeprowadził podział etycznych banków według kryterium misji. Tym samym rozszerzył zakres podmiotowy, tzn. zakwalifikował do podmiotów, potocznie zwanymi bankami etycznymi, inne instytucje pośrednictwa finansowego, które z litery prawa nie są bankami. Według tego autora wyróżnia się cztery grupy banków etycznych:

1. Społecznie odpowiedzialne banki i inne instytucje pośrednictwa finansowego (np. banki zakwalifikowane do indeksów społecznie odpowiedzialnych czy wybrane banki spółdzielcze). 
2. Banki i inne instytucje pośrednictwa finansowego, które wybrały czysto etyczny charakter działalności (np. członkowie FEBEA, INAISE, GABoV, społecznie odpowiedzialne fundusze inwestycyjne).

3. Banki i inne instytucje kredytowe, które otwierają się na nowe rynki (np. mikrokredyty czy ogólnie mikrofinansownie).

4. Banki zaangażowane w działalność charytatywną (np. The Children's Development Bank, fundacje charytatywne).

Tabela 1. Różnice między bankami etycznymi a konwencjonalnymi bankami komercyjnymi

\begin{tabular}{|l|l|}
\hline \multicolumn{1}{|c|}{ Etyczne banki } & \multicolumn{1}{|c|}{ Komercyjne banki } \\
\hline $\begin{array}{l}\text { Działalność oparta na przejrzystym zestawie } \\
\text { wartości etycznych, które są znane, akceptowane } \\
\text { i szanowane na wszystkich poziomach } \\
\text { hierarchii. }\end{array}$ & $\begin{array}{l}\text { Działalność podporządkowana jest osiąnięciu } \\
\text { kilku celów ilościowych, przeważnie takich, jak } \\
\text { udział w rynku oraz rentowność. }\end{array}$ \\
\hline $\begin{array}{l}\text { Dążenie do uzyskania zarówno zysków } \\
\text { finansowych, jak i korzyści społecznych } \\
\text { i środowiskowych. }\end{array}$ & $\begin{array}{l}\text { Koncentracja na maksymalizacji zysków } \\
\text { finansowych nawet poprzez inwestycje } \\
\text { kontrowersyjne pod względem społecznym } \\
\text { i ekologicznym. }\end{array}$ \\
\hline $\begin{array}{l}\text { Decyzje dotyczące inwestycji należą po pierwsze } \\
\text { do klientów (deponentów, kredytobiorców), } \\
\text { poprzez możliwość wyboru etycznych } \\
\text { projektów, które będą finansowane. }\end{array}$ & $\begin{array}{l}\text { Strategia inwestycyjna oraz poziom ryzyka } \\
\text { ustalane przez kierownictwo banku. }\end{array}$ \\
\hline $\begin{array}{l}\text { Regularna publikacja listy wszystkich projektów } \\
\text { inwestycyjnych, które otrzymały dofinasowanie. }\end{array}$ & $\begin{array}{l}\text { Brak informacji na temat przeznaczenia } \\
\text { pozyskanych i pożyczonych funduszy. }\end{array}$ \\
\hline $\begin{array}{l}\text { Finansowanie firm, których projekty pozytywnie } \\
\text { wpływają na społeczeństwo i środowisko. }\end{array}$ & $\begin{array}{l}\text { Przy pozyskiwaniu finansowania nie jest brane } \\
\text { pod uwagę etyczne zachowanie wnioskodawcy } \\
\text { ani wpływ jego działań na społeczeństwo } \\
\text { i środowisko. }\end{array}$ \\
\hline
\end{tabular}

Źródło: [PRICE 2014].

Wśród banków etycznych znajdują się też takie, które łączą cechy banków społecznych i komercyjnych, wchodzą w skład indeksów społecznie odpowiedzialnych lub mają status podmiotów społecznie odpowiedzialnych. Nie są to przykłady typowo etycznej bankowości, jednakże ze względu na jeszcze stosunkowo niedużą liczbę tego typu instytucji zostały wyróżnione jako te, które podejmują działania ukierunkowane na rozwój etycznych finansów.

Zaprezentowany powyżej podział etycznych banków przez R. Milano jest próbą przeprowadzenia jednorodnej systematyzacji. Można zastosować różne kryteria klasyfikacyjne odzwierciedlające różnice zwyczajowe czy kulturowe, jednakże dla potrzeb prowadzonego przez autora badania kryterium podmiotowe wydaje się najwłaściwsze. 


\section{Metodyka badań i przebieg procesu badawczego}

Celem badania jest ustalenie szacunkowego stopnia spełnienia kryteriów Modelu M. Jeuckena przez banki społecznie odpowiedzialne z krajów Europy Środkowo-Wschodniej. Jeucken założył, że jego model służy do oceny banków w krajach rozwiniętych, dla których będą spełnione następujące trzy kryteria:

1) kraje muszą wykazywać wysoki dochód na osobę mierzony wskaźnikiem $\mathrm{PKB} /$ per capita;

2) kraje muszą należeć do grupy tzw. krajów znajdujących się na liście Programu Narodów Zjednoczonych [Human Development Index, UNDP 2000];

3) badane banki muszą prowadzić transparentna politykę informacyjną.

W grupie tej nie znalazły się banki z takich krajów, jak: Czechy, Polska, Słowacja, Węgry, natomiast został wyłoniony jeden bank z Austrii (Bank Austria).

Dużą wartością Modelu Jeuckena jest to, że daje możliwość oceny działań społecznie odpowiedzialnych (jakościowych) i wyrażenia efektów oceny w sposób ilościowy. Czynniki jakościowe w modelu zostały zaszeregowane do pięciu grup; każda $\mathrm{z}$ grup jest ważona udziałem w zależności od oczekiwanego efektu (siły wpływu na działania społecznie odpowiedzialne banków). Grupy są następujące:

I. komunikacja (z otoczeniem) z wagą $10 \%$,

II. dostępność publikowanych informacji z wagą $25 \%$,

III. dostępność finansowania (rozumiana jako zasady oceny zdolności kredytowej i oceny ryzyka dla banku) z wagą $15 \%$,

IV. dostępność odpowiedzialnych społecznie produktów finansowych z wagą $40 \%$,

V. kwestie społeczne i działalność charytatywna z wagą $10 \%$.

Żadna z grup oceny nie ma wagi powyżej 50\%, aczkolwiek grupa czwarta ma najwyższy wpływ na postrzeganie banku jako społecznie odpowiedzialnego. W każdej grupie zostały wyspecyfikowane i oszacowane elementy oceny. Elementy te różnią się siłą wpływu, natomiast suma punktów dla poszczególnych grup jest taka sama i wynosi 20 pkt (tab. 2).

Przedmiot badań został zawężony do banków notowanych na giełdach Europy Środkowo-Wschodniej, spełniających najwyższe standardy społecznej odpowiedzialności, notowanych w ramach indeksów społecznie odpowiedzialnych, takich jak RESPECT, VONIX i CEERIUS. Na drodze selekcji wybrano 9 banków; 5 banków z indeksu RESPECT (Bank Millennium SA, BZ WBK SA, Bank Handlowy SA, ING Bank Śląski SA, Bank Pekao SA), trzy banki z indeksu VONIX (Raiffeisen Bank International AG, BKS Bank AG, Erste Group Bank AG) i jeden bank z indeksu CEERIUS (OTP Bank). Jednocześnie Bank Millennium jest notowany w ramach indeksu RESPECT i CEERIUS.

Aby w odpowiedni sposób zrealizować cel badania, opracowana została autorska technika badawcza polegająca na analizie treści witryn internetowych (content analysis), poprzedzona wnikliwym badaniem literatury. Dzięki analizie treści witryn 
internetowych przebadano i oceniono przekaz banków notowanych w ramach indeksów społecznie odpowiedzialnych. Warunkiem koniecznym uzyskania przez banki pozytywnej weryfikacji $\mathrm{w}$ zakresie poszczególnych elementów wymienionych $\mathrm{w}$ tabeli 2 . było ustalenie ich występowania $\mathrm{w}$ chociaż jednym $\mathrm{z}$ badanych banków. Zastosowano metodę ,jest lub brak". Poziom ,jest” został skalibrowany z poziomem maksymalnym dopuszczalnym w Modelu M. Jeuckena. Poziomowi „brak” zostało nadane 0 pkt.

\section{Wyniki i wnioski z prowadzonych badań}

W tabeli 2 przedstawiono zakres dopasowania badanych banków do Modelu M. Jeuckena. Poziom dopasowania badanej próby wyliczono i przedstawiono w tabeli 3 i wynosi on $60,25 \%$. Wynik przeprowadzonego badania wskazuje, że badana grupa banków nie spełnia części kryteriów modelu.

Tabela 2. Dopasowanie badanych banków do Modelu M. Jeuckena

\begin{tabular}{|c|c|c|c|c|c|c|c|}
\hline Grupa & Elementy oceny & $\mathrm{P}$ & $\mathrm{D}$ & Grupa & Elementy oceny & $\mathrm{P}$ & $\mathrm{D}$ \\
\hline 1 & 2 & 3 & 4 & 5 & 6 & 7 & 8 \\
\hline I.1 & Polityka środowiskowa & 4 & $\mathrm{x}$ & II.5 & $\begin{array}{l}\text { Dane jakościowe dotyczące troski } \\
\text { o środowisko naturalne (aspekt } \\
\text { zewnętrzny) }\end{array}$ & 1 & $\mathrm{x}$ \\
\hline I. 2 & Raporty środowiskowe & 5 & $\mathrm{x}$ & II.6 & $\begin{array}{l}\text { Cele dotyczące troski } \\
\text { o środowisko w przyszłości } \\
\text { (aspekt zewnętrzny) }\end{array}$ & 5 & $\mathrm{x}$ \\
\hline $\mathrm{I} .3$ & $\begin{array}{l}\text { Członkostwo w Światowej } \\
\text { Radzie Biznesu na rzecz ZR }\end{array}$ & 1 & - & III.1 & Analiza ryzyka środowiskowego & 8 & - \\
\hline I.4 & $\begin{array}{l}\text { Sygnatariusze Deklaracji } \\
\text { Ochrony Środowiska NZ }\end{array}$ & 3 & - & III. 2 & $\begin{array}{l}\text { Sektory wykluczone bez } \\
\text { możliwości finansowania }\end{array}$ & 4 & - \\
\hline 1.5 & $\begin{array}{l}\text { Sygnatariusze Deklaracji } \\
\text { w sprawie zasad rozwoju } \\
\text { zasobów z } 2011 \mathrm{r} \text {. }\end{array}$ & 1 & - & III.3 & $\begin{array}{l}\text { Przestrzeganie wytycznych } \\
\text { Banku Światowego dotyczących } \\
\text { finasowania }\end{array}$ & 5 & $\mathrm{x}$ \\
\hline 1.6 & $\begin{array}{l}\text { Certyfikaty zarządzania } \\
\text { środowiskowego }\end{array}$ & 6 & $\mathrm{x}$ & III.4 & $\begin{array}{l}\text { Przestrzeganie wytycznych } \\
\text { OECD dla działalności } \\
\text { gospodarczej w krajach } \\
\text { rozwijających się }\end{array}$ & 3 & - \\
\hline II.1 & $\begin{array}{l}\text { Dane ilościowe dotyczące } \\
\text { troski o środowisko naturalne } \\
\text { (aspekt wewnętrzy) }\end{array}$ & 4 & $\mathrm{x}$ & IV.1 & Kredyty środowiskowe & 2 & - \\
\hline II. 2 & $\begin{array}{l}\text { Dane jakościowe dotyczące } \\
\text { troski o środowisko } \\
\text { naturalne (aspekt wewnętrzy }\end{array}$ & 1 & $\mathrm{x}$ & IV.2 & $\begin{array}{l}\text { Społecznie odpowiedzialne } \\
\text { fundusze lub doradztwo } \\
\text { inwestycyjne }\end{array}$ & 2 & $\mathrm{x}$ \\
\hline II. 3 & $\begin{array}{l}\text { Cele dotyczące troski o } \\
\text { środowisko w przyszłości } \\
\text { (aspekt wewnętrzny) }\end{array}$ & 5 & $\mathrm{x}$ & IV.3 & Leasing środowiskowy & 2 & - \\
\hline
\end{tabular}


Tabela 2, cd.

\begin{tabular}{|c|c|c|c|c|c|c|c|}
\hline 1 & 2 & 3 & 4 & 5 & 6 & 7 & 8 \\
\hline II.4 & $\begin{array}{l}\text { Dane ilościowe dotyczące } \\
\text { troski o środowisko } \\
\text { naturalne (aspekt zewnętrzy) }\end{array}$ & 4 & $\mathrm{x}$ & IV.4 & $\begin{array}{l}\text { Produkty oszczędnościowe } \\
\text { środowiskowe }\end{array}$ & 1 & $\mathrm{x}$ \\
\hline IV.5 & $\begin{array}{l}\text { Ubezpieczenie szkód na } \\
\text { rzecz środowiska }\end{array}$ & 2 & $\mathrm{x}$ & IV.10 & Produkty klimatyczne & 2 & - \\
\hline IV.6 & $\begin{array}{l}\text { Doradztwo wpływające na } \\
\text { ochronię środowiska przez } \\
\text { klienta }\end{array}$ & 2 & - & V.1 & $\begin{array}{l}\text { Karty kredytowe } \mathrm{z} \text { benefitami } \\
\text { na rzecz ochrony środowiska }\end{array}$ & 4 & $\mathrm{x}$ \\
\hline IV.7 & $\begin{array}{l}\text { Venture capital nakierowane } \\
\text { na ochronę środowiska }\end{array}$ & 3 & - & V.2 & $\begin{array}{l}\text { Sponsoring na rzecz ochrony } \\
\text { środowiska }\end{array}$ & 2 & $\mathrm{x}$ \\
\hline IV.8 & Mikrokredyty & 3 & - & V.3 & $\begin{array}{l}\text { Zaangażowanie społeczne } \\
\text { np. na rzecz społeczności lokalnej }\end{array}$ & 8 & $\mathrm{x}$ \\
\hline IV.9 & $\begin{array}{l}\text { Konwersja dhugu na } \\
\text { inwestycje środowiskowe } \\
\text { (debt-for-nature swaps) }\end{array}$ & 1 & - & V.4 & $\begin{array}{l}\text { Wewnętrzne społeczno- } \\
\text {-ekonomiczne aspekty }\end{array}$ & 6 & $\mathrm{x}$ \\
\hline
\end{tabular}

$\mathrm{P}$ - punkty, D - dostępność, (x) - jest, (-) - brak

Źródło: opracowanie własne na podstawie [Jeucken 2004].

Tabela 3. Maksymalna liczba punktów dostępna w Modelu M. Jeuckena i w badanej próbie

\begin{tabular}{|c|c|c|c|c|c|c|c|}
\hline \multicolumn{5}{|c|}{ Model M. Jeuckena } & \multicolumn{5}{c|}{ Badana próba } \\
\hline grupa & $\mathrm{P}$ & $\mathrm{W}(\mathrm{w} \%)$ & $S O_{\max }$ & grupa & $\mathrm{P}$ & $\mathrm{W}(\mathrm{w} \%)$ & $S O_{\max }$ \\
\hline I & 20 & 10 & 2 & $\mathrm{I}$ & 15 & 10 & 1,5 \\
\hline II & 20 & 25 & 5 & II & 20 & 25 & 5 \\
\hline III & 20 & 15 & 3 & III & 5 & 15 & 0,75 \\
\hline IV & 20 & 40 & 8 & IV & 7 & 40 & 2,8 \\
\hline V & 20 & 10 & 2 & V & 20 & 10 & 2 \\
\hline & & & 20 & & & & 12,5 \\
& & & $(100 \%)$ & & & & $(60,25 \%)$ \\
\hline
\end{tabular}

$\mathrm{P}$ - punkty, W - waga, SO - społeczna odpowiedzialność, $\sum_{s O \max }=\sum_{i=1}^{m} p_{i} w_{i}$

Źródło: opracowanie własne.

Najlepsze wyniki dopasowania występują w grupie drugiej i piątej - wskaźnik dopasowania jest maksymalny. Wprawdzie banki uzyskały bardzo dobry wynik w tym zakresie, jednakże zauważono duże dysproporcje, szczególnie w grupie drugiej „dostępność publikowanych informacji” w przekazach badanych banków w porównaniu z bankami z krajów w Modelu M. Jeuckena. Zróżnicowanie to polega na jakości sporządzonych informacji (pełne, wyczerpujące informacje, potwierdzone danymi ilościowymi, sformułowane jasno cele), dotyczących zarówno polityki wewnętrznej banku, jak i polityki regionu. Grupa pierwsza ,komunikacja” także wykazuje wysoki stopień dopasowania, aczkolwiek nie maksymalny. W modelu autor 
przywiązuje wagę do członkostwa w różnych organizacjach międzynarodowych, a w badaniu banki nie przekazywały takich informacji. Na uwagę jednak zasługuje fakt, że badane banki w większości prowadziły dobrą politykę informacyjną, przygotowując wyczerpujące raporty czy legitymując się certyfikatami zarządzania środowiskowego.

Najgorsze wyniki dopasowania występują w grupie trzeciej (5 pkt na 20 możliwych) i czwartej (7 pkt na 20 możliwych). Największy wpływ na wynik oceny ma grupa czwarta „dostępność odpowiedzialnych społecznie produktów finansowych”. Niski stopień dopasowania w grupie trzeciej i czwartej może wynikać ze słabości oferty produktowej i niskimi standardami środowiskowymi w Europie Środkowo-Wschodniej, przy jednoczesnym bardzo wysokim wartościowaniu tych standardów w modelu.

\section{Zakończenie}

Wybrane banki z Europy Środkowo-Wschodniej stosują najwyższe standardy społeczne i środowiskowe, a mimo to nie są w pełni dopasowane do modelu. Należy podkreślić, że model został opracowany na początku XXI w. (publikacja w 2004 r.), a więc prawie 13 lat temu, i chociażby ze względu na wzrost świadomości społecznej i ekologicznej powinien ulec modyfikacji w swojej podstawowej formie. Należałoby się zastanowić nad prowadzeniem badań wielotorowo, przygotowując modele, które $\mathrm{z}$ równą uwagą byłyby wstanie ocenić poziom zaangażowania banków, uwzględniając zróżnicowanie regionalne i zróżnicowanie podmiotowe w samych bankach (banki komercyjne, banki komercyjne ze statusem społecznie odpowiedzialnych, banki spółdzielcze i inne). Dodatkowo uwidoczniło się w modelu eksponowanie czynników ekologicznych kosztem czynników społecznych.

Duża słabość badanych banków uwidoczniła się w ofercie produktowej; jednym z powodów może być brak zgłaszanego popytu na takie produkty, jak np. venture capital nakierowane na ochronę środowiska, mikrokredyty, konwersja długu na inwestycje środowiskowe czy produkty klimatyczne. Jest to bardzo ważny aspekt działalności społecznie odpowiedzialnej banków, gdyż istotą ich działania jest nie tylko angażowanie się w akcje promocyjne dotyczące aspektów społecznych i ekologicznych, ale przede wszystkim oferowanie produktów mających istotny pozytywny wpływ na środowisko i społeczeństwo.

\section{Literatura}

Arvidsson A., Peitersen N., 2013, The Ethical Economy. Rebuilding Value After the Crisis, Columbia University Press.

De Clerck F., 2009, Ethical banking, [w:] Zsolnai L. (ed.), Ethical Prospects-Economy, Society, and Environment, Berlin, Heidelberg and New York: Springer, 209-27, http://dx.doi.org/10.1007/9781-4020-9821-5_10 (5.02.2017). 
Dowd K., 2009, Moral Hazard and the Financial Crisis, Cato Journal, no. 1 (29), s. 141-166. Jeucken M., 2004, Sustainability in Finance. Banking on the Planet, Eburon Publishers, Delft.

Milano R., 2011, Social banking, [w:] Weber O., Remer S. (ed.), Social Banking and the Future of Sustainable Finance, Routledge, Taylor \& Francis Group, s. 15-47.

Moshirian F., 2011, The Global Financial Crisis and the Evolution of Markets, Institutions and Regulation, Journal of Banking \& Finance, no 3 (35), s. 502-511. DOI:10.1016/j.jbankfin.2010.08.010.

PRICE, 2014, Wprowadzenie do etycznego finansowania i odpowiedzialnych inwestycji, red. Makulski T., Skowera A., http://www.sprawiedliwyhandel.pl/wp-content/uploads/2017/01/Wprowadzenie-doetycznego-finansowania-i-odpowiedzialnych-inwestycji.pdf (5.02.2017).

Remer S., 2011, Social banking at the crossroads, [w:] Weber O., Remer S. (ed.), Social Banking and the Future of Sustainable Finance, Routledge, Taylor \& Francis Group, s. 136-195.

UNDP, 2000, Human Development Reports, http://hdr.undp.org/en/content/human-development-report-2000 (5.02.2017).

Weber O., Remer S., 2011, Social Banks and the Future of Sustainable Finance, Routledge, Taylor \& Francis Group. 